Case Report

\title{
New-Onset Kidney Diseases after COVID-19 Vaccination: A Case Series
}

\author{
Jeong-Hoon Lim ${ }^{1} \mathbb{1}$, Mee-Seon Kim ${ }^{2}{ }^{\mathbb{D}}$, Yong-Jin Kim ${ }^{2}$, Man-Hoon Han ${ }^{2}$, Hee-Yeon Jung ${ }^{1}$, Ji-Young Choi ${ }^{1}$,

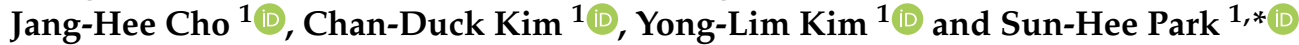

check for

updates

Citation: Lim, J.-H.; Kim, M.-S.; Kim, Y.-J.; Han, M.-H.; Jung, H.-Y.; Choi,

J.-Y.; Cho, J.-H.; Kim, C.-D.; Kim,

Y.-L.; Park, S.-H. New-Onset Kidney

Diseases after COVID-19 Vaccination:

A Case Series. Vaccines 2022, 10, 302.

https://doi.org/10.3390/

vaccines 10020302

Academic Editors: Eyal Klement and

Tusneaki Kenzaka

Received: 13 January 2022

Accepted: 14 February 2022

Published: 16 February 2022

Publisher's Note: MDPI stays neutral with regard to jurisdictional claims in published maps and institutional affiliations.

Copyright: (C) 2022 by the authors. Licensee MDPI, Basel, Switzerland. This article is an open access article distributed under the terms and conditions of the Creative Commons Attribution (CC BY) license (https:// creativecommons.org/licenses/by/ $4.0 /)$.
1 Division of Nephrology, Department of Internal Medicine, School of Medicine, Kyungpook National University, Kyungpook National University Hospital, Daegu 41944, Korea; jh-lim@knu.ac.kr (J.-H.L.); hy-jung@knu.ac.kr (H.-Y.J.); jy-choi@knu.ac.kr (J.-Y.C.); jh-cho@knu.ac.kr (J.-H.C.); drcdkim@knu.ac.kr (C.-D.K.); ylkim@knu.ac.kr (Y.-L.K.)

2 Department of Pathology, School of Medicine, Kyungpook National University, Kyungpook National University Hospital, Daegu 41944, Korea; kimm2342@gmail.com (M.-S.K.); yyjjkim@knu.ac.kr (Y.-J.K.); mhhan1@knu.ac.kr (M.-H.H.)

* Correspondence: sh-park@knu.ac.kr; Tel.: +82-53-200-5547; Fax: +82-53-426-9464

\begin{abstract}
Various vaccines against COVID-19 have been developed and proven to be effective, but their side effects, especially on kidney function, are not yet known in detail. In this study, we report the clinical courses and histopathologic findings of new-onset kidney diseases after COVID-19 vaccination as confirmed via kidney biopsy. Five patients aged 42 to 77 years were included in this study, and baseline kidney function was normal in all patients. The biopsy-proven diagnosis indicated newly developed kidney diseases: (1) IgA nephropathy presenting with painless gross hematuria, (2) minimal change disease presenting with nephrotic syndrome, (3) thrombotic microangiopathy, and (4) two cases of acute tubulointerstitial nephritis presenting with acute kidney injury. Individualized treatment was applied as per disease severity and underlying pathology, and the treatment outcomes of all patients were improved. Since this is not a controlled study, the specific pathophysiologic link and causality between the incidence of kidney diseases and COVID-19 vaccination are difficult to confirm. However, clinicians need to consider the possibility that kidney diseases may be provoked by vaccines in patients who have renal symptoms.
\end{abstract}

Keywords: COVID-19; vaccination; kidney disease; kidney biopsy; IgA nephropathy; minimal change disease; thrombotic microangiopathy; tubulointerstitial nephritis

\section{Introduction}

The coronavirus disease 2019 (COVID-19) pandemic, which is caused by severe acute respiratory syndrome coronavirus 2 (SARS-CoV-2) infection, is still ongoing globally. Although therapeutic agents that successfully suppress COVID-19 have not yet been developed, several vaccines against SARS-CoV-2 can help in the prevention of COVID-19 and alleviation of the disease's severity.

Two main types of vaccine are currently used to prevent COVID-19: (1) mRNA vaccines, such as BNT162b2 (Pfizer-BioNTech) and mRNA-1273 (Moderna); and (2) vectored vaccines, such as AZD1222 (Oxford-AstraZeneca) and Ad26.COV2.S (Janssen). Several clinical studies have demonstrated that these vaccines have excellent protective effects against COVID-19, but their side effects are not yet well-known [1,2]. To prove a causal relationship between side effects after vaccination is difficult, so the side effects of vaccines are occasionally overlooked.

Several studies have reported on kidney diseases that occurred after COVID-19 vaccinations, but the number of cases was few, and the histopathologic abnormalities and clinical courses were heterogeneous $[3,4]$. This limited information could delay the diagnosis and treatment of renal side effects after COVID-19 vaccination, resulting in a poor prognosis. 
Therefore, in this study, we present five cases of new-onset renal pathology confirmed by kidney biopsy from a tertiary hospital in Korea, which were clinically presented as acute kidney injury or urinary abnormalities after COVID-19 vaccination. Table 1 shows the details of the cases. 
Table 1. Summary of presented cases of new-onset renal histopathology.

\begin{tabular}{|c|c|c|c|c|c|c|c|c|c|c|c|}
\hline $\begin{array}{l}\text { Pathologic } \\
\text { Diagnosis }\end{array}$ & $\begin{array}{l}\text { Age/ } \\
\text { Sex }\end{array}$ & $\begin{array}{l}\text { Clinical Pre- } \\
\text { sentation }\end{array}$ & $\begin{array}{l}\text { Underlying } \\
\text { Diseases }\end{array}$ & $\begin{array}{c}\text { Types of } \\
\text { Vaccine/ } \\
\text { Manufacturer/ } \\
\text { Dose }\end{array}$ & $\begin{array}{c}\text { Symptom } \\
\text { Onset } \\
\text { Time/Biopsy } \\
\text { Time after } \\
\text { Vaccination, } \\
\text { Days } \\
\end{array}$ & Kidney Histopathology & $\begin{array}{c}\text { Scr at } \\
\text { Baseline, } \\
\text { mg/dL }\end{array}$ & $\begin{array}{l}\text { Scr at } \\
\text { Biopsy, } \\
\mathrm{mg} / \mathrm{dL}\end{array}$ & $\begin{array}{l}\text { UPCR at } \\
\text { Biopsy, } \\
\text { g/gCr }\end{array}$ & Treatment & $\begin{array}{c}\text { Response } \\
\text { (Follow-Up } \\
\text { Duration after } \\
\text { Diagonsis) }\end{array}$ \\
\hline $\begin{array}{l}\text { IgA } \\
\text { nephropa- } \\
\text { thy, Haas III } \\
\text { (M0E1C1S1T0) }\end{array}$ & $42 / \mathrm{F}$ & $\begin{array}{c}\text { Gross } \\
\text { hematuria }\end{array}$ & None & $\begin{array}{l}\text { mRNA/ } \\
\text { Moderna } \\
\text { (Cambridge, } \\
\text { MA, USA)/ } \\
\text { 2nd }\end{array}$ & $1 / 54$ & $\begin{array}{l}\text { LM: mesangial hypercellular } \\
\text { with increased mesangial } \\
\text { matrix, cellular crescent, } \\
\text { segmental sclerosis, } \\
\text { endocapillary proliferation } \\
\text { IF: IgA 3+, C3 1+, kappa 2+, } \\
\text { lambda 2+ } \\
\text { EM: many large mesangial } \\
\text { electron dense deposits, focal } \\
\text { foot process loss }\end{array}$ & $\begin{array}{c}0.47 \text { at } 5 \text { weeks } \\
\text { before biopsy }\end{array}$ & 0.45 & 1.67 & RASi & PR (11 weeks) \\
\hline $\begin{array}{l}\text { Minimal } \\
\text { change } \\
\text { disease }\end{array}$ & $52 / \mathrm{M}$ & $\begin{array}{l}\text { Nephrotic } \\
\text { syndrome }\end{array}$ & None & $\begin{array}{l}\text { Vector/ } \\
\text { Janssen } \\
\text { (Raritan, NJ, } \\
\text { USA)/ } \\
\text { 1st }\end{array}$ & $7 / 33$ & $\begin{array}{l}\text { LM: normal glomeruli, intact } \\
\text { tubules and interstitium } \\
\text { IF: all negative } \\
\text { EM: diffuse foot process loss }\end{array}$ & NA (normal) & 1.96 & 7.12 & $\begin{array}{l}\text { High-dose } \\
\text { steroid } \\
\text { treatment }\end{array}$ & CR (31 weeks) \\
\hline
\end{tabular}


Table 1. Cont.

\begin{tabular}{|c|c|c|c|c|c|c|c|c|c|c|c|}
\hline $\begin{array}{l}\text { Pathologic } \\
\text { Diagnosis }\end{array}$ & $\begin{array}{l}\text { Age/ } \\
\text { Sex }\end{array}$ & $\begin{array}{l}\text { Clinical Pre- } \\
\text { sentation }\end{array}$ & $\begin{array}{l}\text { Underlying } \\
\text { Diseases }\end{array}$ & $\begin{array}{c}\text { Types of } \\
\text { Vaccine/ } \\
\text { Manufacturer/ } \\
\text { Dose }\end{array}$ & $\begin{array}{c}\text { Symptom } \\
\text { Onset } \\
\text { Time/Biopsy } \\
\text { Time after } \\
\text { Vaccination, } \\
\text { Days } \\
\end{array}$ & Kidney Histopathology & $\begin{array}{c}\text { Scr at } \\
\text { Baseline, } \\
\text { mg/dL }\end{array}$ & $\begin{array}{l}\text { Scr at } \\
\text { Biopsy, } \\
\mathrm{mg} / \mathrm{dL}\end{array}$ & $\begin{array}{l}\text { UPCR at } \\
\text { Biopsy, } \\
\text { g/gCr }\end{array}$ & Treatment & $\begin{array}{c}\text { Response } \\
\text { (Follow-Up } \\
\text { Duration after } \\
\text { Diagonsis) }\end{array}$ \\
\hline $\begin{array}{l}\text { Acute tubu- } \\
\text { lointerstitial } \\
\text { nephritis }\end{array}$ & $44 / \mathrm{M}$ & $\begin{array}{l}\text { Acute } \\
\text { kidney } \\
\text { injury }\end{array}$ & $\begin{array}{c}\text { Type } 2 \\
\text { diabetes } \\
\text { mellitus, } \\
\text { chronic } \\
\text { hepatitis B, hy- } \\
\text { perlipidemia }\end{array}$ & $\begin{array}{c}\text { mRNA/ } \\
\text { Moderna } \\
\text { (Cambridge, } \\
\text { MA, USA)/ } \\
\text { 1st }\end{array}$ & $1 / 28$ & $\begin{array}{l}\text { LM: normal glomeruli, mild } \\
\text { IF/TA, massive mixed } \\
\text { inflammatory cell infiltrates in } \\
\text { the tubular epithelium } \\
\text { (tubulitis) and interstitium } \\
\text { IF: all negative } \\
\text { EM: normal glomeruli }\end{array}$ & $\begin{array}{c}0.91 \text { at } 10 \\
\text { weeks before } \\
\text { biopsy }\end{array}$ & 4.94 & 1.01 & $\begin{array}{l}\text { High-dose } \\
\text { steroid } \\
\text { treatment }\end{array}$ & PR (11 weeks) \\
\hline $\begin{array}{l}\text { Acute tubu- } \\
\text { lointerstitial } \\
\text { nephritis } \\
\text { with } \\
\text { myoglobin } \\
\text { tubular casts }\end{array}$ & $77 / \mathrm{F}$ & $\begin{array}{l}\text { Acute } \\
\text { kidney } \\
\text { injury }\end{array}$ & $\begin{array}{l}\text { Chronic } \\
\text { hepatitis B, } \\
\text { hepatocellular } \\
\text { carcinoma, } \\
\text { type } 2 \text { diabetes } \\
\text { mellitus }\end{array}$ & $\begin{array}{l}\text { mRNA/ } \\
\text { Pfizer (New } \\
\text { York, NY, } \\
\text { USA)/ } \\
\text { 2nd }\end{array}$ & $1 / 14$ & $\begin{array}{l}\text { LM: normal glomeruli, mild } \\
\text { IF/TA, infiltration of the } \\
\text { inflammatory cells in the } \\
\text { interstitium, myoglobin casts in } \\
\text { the tubules } \\
\text { IF: all negative } \\
\text { EM: electron dense granular } \\
\text { casts in tubules, focal foot } \\
\text { process loss }\end{array}$ & $\begin{array}{c}0.98 \text { at } 12 \\
\text { weeks before } \\
\text { biopsy }\end{array}$ & 11.15 & 4.63 & $\begin{array}{l}\text { Low-dose } \\
\text { steroid } \\
\text { treatment, } \\
\text { hemodialy- } \\
\text { sis }\end{array}$ & PR (23 weeks) \\
\hline
\end{tabular}

Abbreviations: Scr, serum creatinine; UPCR, urine protein-to-creatinine ratio; M, mesangial hypercellularity; E, endocapillary hypercellularity; C, crescents; S, segmental glomerulosclerosis; T, tubular atrophy/interstitial fibrosis; LM, light microscopy; IF, immunofluorescence; EM, electron microcopy; RASi, renin angiotensin system inhibitor; PR, partial remission; $\mathrm{CR}$, complete remission; SR, spontaneous remission; IF/TA, tubular atrophy and interstitial fibrosis. 


\section{Case Presentation}

2.1. IgA Nephropathy Presenting with Painless Gross Hematuria

A healthy 42-year-old woman presented with first-onset painless gross hematuria and proteinuria. She had no family history of kidney diseases. She had received two doses of the mRNA-1273 vaccine with a 4-week interval. One day after receiving the second dose, she developed dark reddish urine. Gross hematuria disappeared within several days, but follow-up urinalysis showed persistent microscopic hematuria and proteinuria. Based on the laboratory data, the serum creatinine level was $0.47 \mathrm{mg} / \mathrm{dL}$, and the $24 \mathrm{~h}$ urinary protein level was $1.7 \mathrm{~g} /$ day. Serologic evaluation revealed no specific abnormalities in viral markers or autoantibodies. A kidney biopsy was performed 8 weeks after the vaccination, and the results are shown in Figure 1. Light microscopy revealed mesangial hypercellularity with increased mesangial matrix, cellular crescent, segmental sclerosis, and endocapillary proliferation. Immunofluorescence revealed 3+ diffuse mesangial staining for IgA. Electron microscopy was also consistent with $\operatorname{Ig}$ A nephropathy, and the Oxford MEST-C classification was M0E1C1S1T0. She was treated with losartan (50 mg), and the spot urine protein-to-creatinine ratio was decreased to $0.7 \mathrm{~g} / \mathrm{g}$.

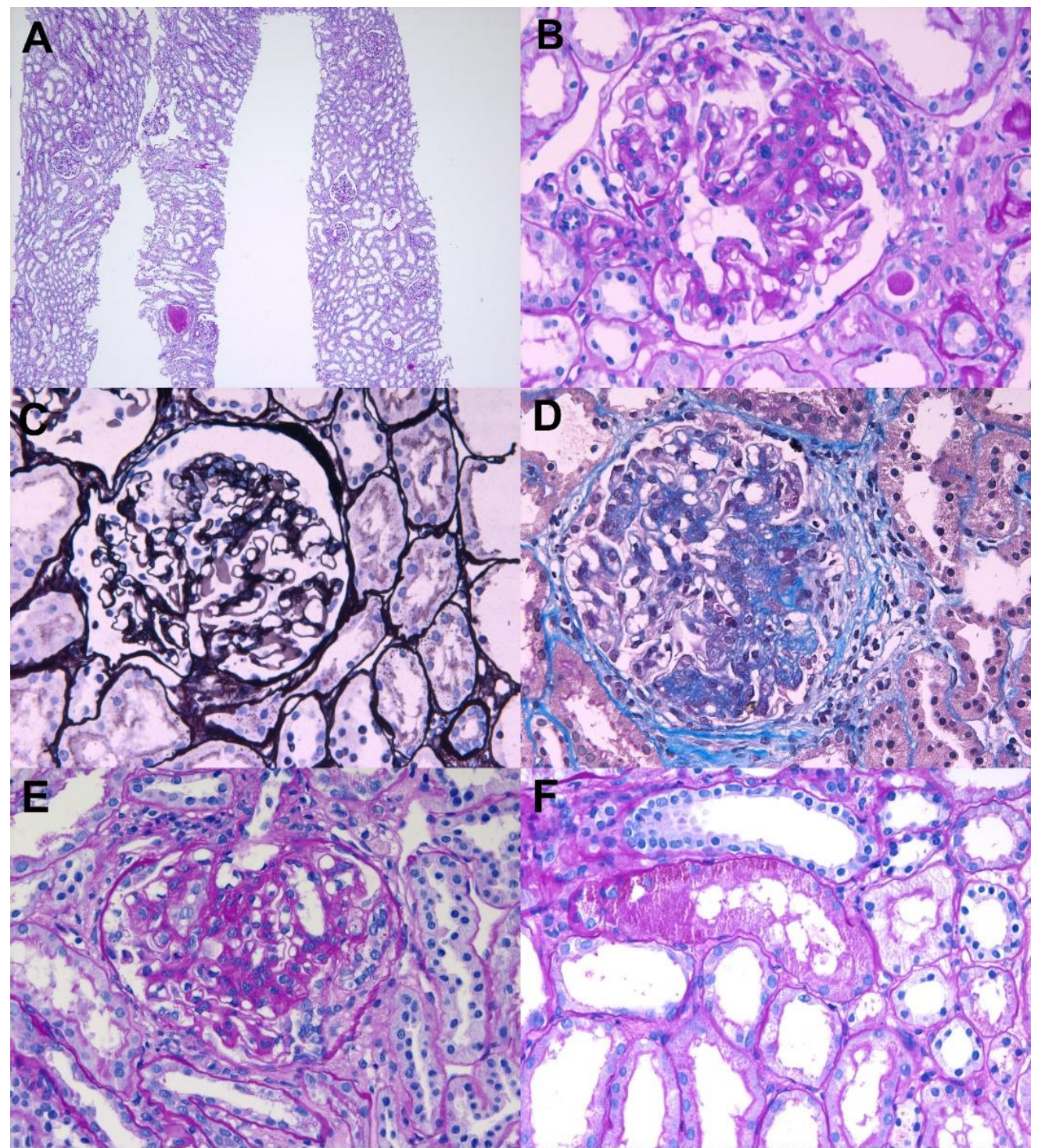

Figure 1. Cont. 

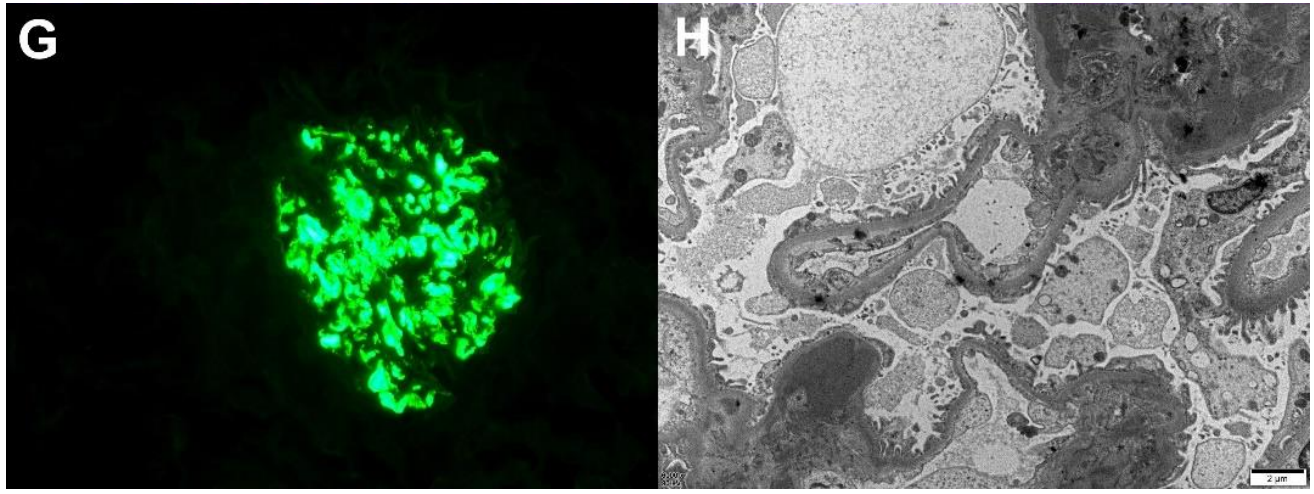

Figure 1. Pathological findings of IgA nephropathy. Light microscopy: (A) In low magnification, no tubular atrophy or interstitial fibrosis was present (periodic acid-Schiff, $\times 40$ ). (B) The glomerulus shows mesangial hypercellularity with increased mesangial matrix (periodic acid-Schiff, $\times 400$ ). (C) The glomerulus shows endocapillary hypercellularity with focal loss of capillary penetrations (periodic acid methenamine silver, $\times 400$ ). (D) The glomerulus shows segmental glomerulosclerosis (Masson's trichrome, $\times 400$ ). (E) The glomerulus shows cellular crescent with endocapillary hypercellularity (periodic acid-Schiff, $\times 400$ ). (F) The picture shows protein reabsorption vacuoles in tubules, which is evidence of proteinuria (periodic acid-Schiff, $\times 400$ ). Immunofluorescence: $(G)$ Strong $\operatorname{IgA}$ mesangial positivity in the immunofluorescence stain $(\times 400)$. Electron microscopy: $(\mathbf{H})$ Numerous large electron-dense deposits in the mesangial areas with focal foot process effacement in the capillary surface were observed $(\times 6000,80 \mathrm{kv})$.

\subsection{Minimal Change Disease Presenting with Nephrotic Syndrome}

A healthy 51-year-old man with no significant past medical history was referred to our clinic because of severe generalized edema. The edema had occurred 7 days after receiving the first dose of Ad26.COV.2 vaccine, and he gained $14 \mathrm{~kg}$ for 3 weeks after vaccination. The laboratory examinations revealed a serum creatinine level of $1.54 \mathrm{mg} / \mathrm{dL}$, an albumin level of $1.6 \mathrm{~g} / \mathrm{dL}$, and a $24 \mathrm{~h}$ urinary protein level of $8.6 \mathrm{~g} / \mathrm{day}$. The serologic markers for glomerulonephritis, including viral markers, were all negative. A kidney biopsy was performed 33 days after the vaccination, and the results are shown in Figure 2. Diffuse effacement of the podocyte foot processes was observed on the electron microscopy, and no specific findings from the light microscopy and immunofluorescence were recorded. He was treated with a high-dose steroid treatment $(1 \mathrm{mg} / \mathrm{kg}$ prednisone), and complete remission was achieved after 3 weeks of treatment.
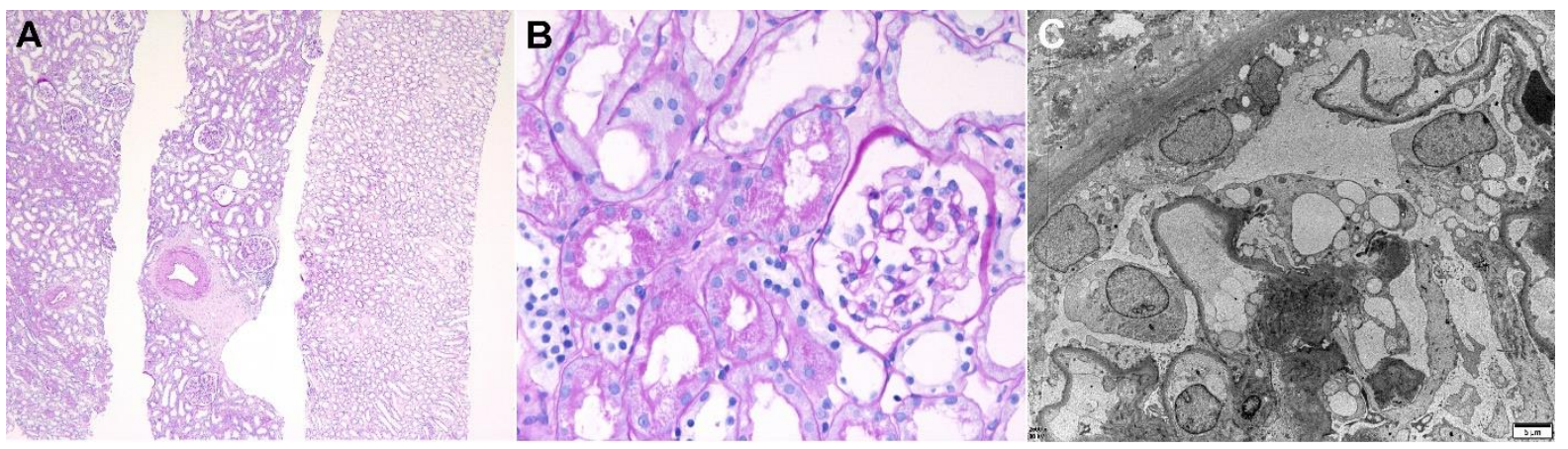

Figure 2. Pathologic findings of minimal change disease. Light microscopy: (A) In low magnification, no tubular atrophy or interstitial fibrosis was present (hematoxylin and eosin, $\times 40$ ). (B) The picture shows a normally appearing glomerulus with protein reabsorption granules in tubules (hematoxylin and eosin, $\times 400$ ). Electron microscopy: (C) Diffuse podocyte foot process effacement with microvillous transformation without electron-dense deposits were observed. The thickness of glomerular basememt membrane was normal $(\times 2500,80 \mathrm{kv})$. 


\subsection{Thrombotic Microangiopathy Presenting with Acute Kidney Injury}

A 69-year-old woman with type 2 diabetes mellitus visited the emergency room because of azotemia and thrombocytopenia. She received her first dose of the AZD1222 vaccine 5 days prior to her visit, and general weakness and gastrointestinal discomfort were observed 2 days later. Based on the laboratory examination, the hemoglobin level was $8.5 \mathrm{~g} / \mathrm{dL}$, platelet count $38 \times 10^{9} / \mathrm{L}$, serum creatinine level $3.69 \mathrm{mg} / \mathrm{dL}$, and spot urine protein-to-creatinine ratio $2.7 \mathrm{~g} / \mathrm{g}$. The serologic evaluation for glomerulonephritis was all-negative. A kidney biopsy was performed 2 weeks after the vaccination, and the results are shown in Figure 3. Light microscopy revealed diffuse thickening of the capillary wall with capillary loop doubling and hyaline thrombi in the glomeruli with intact tubule and interstitium. Immunofluorescence for fibrinogen revealed a strong positivity in the glomeruli. Electron microscopy revealed duplications of the glomerular basement membranes (GBM), endothelial swelling and hypertrophy with occlusion of the lumens, and glomerular intracapillary fibrin deposition with entrapped cellular debris. The pathological findings indicated chronic thrombotic microangiopathy (TMA). In addition, the ADAMTS13 activity was $68.9 \%$, and the Shiga toxin result was negative. Acute kidney injury and thrombocytopenia gradually and spontaneously resolved, the serum creatinine level decreased to $0.65 \mathrm{mg} / \mathrm{dL}$, and the spot urine protein-to-creatinine ratio was $1.0 \mathrm{~g} / \mathrm{g}$ 8 weeks after the vaccination.

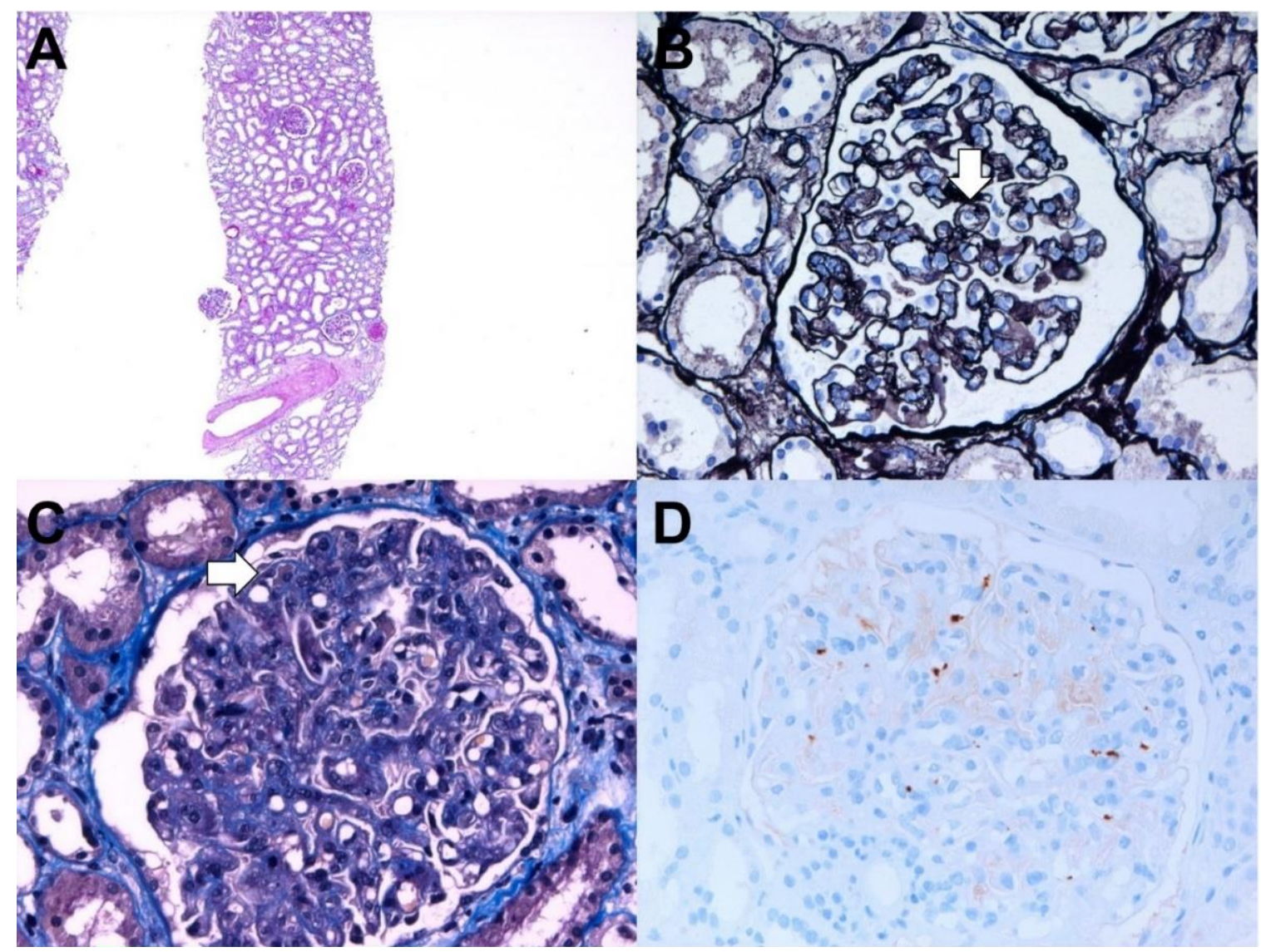

Figure 3. Cont. 


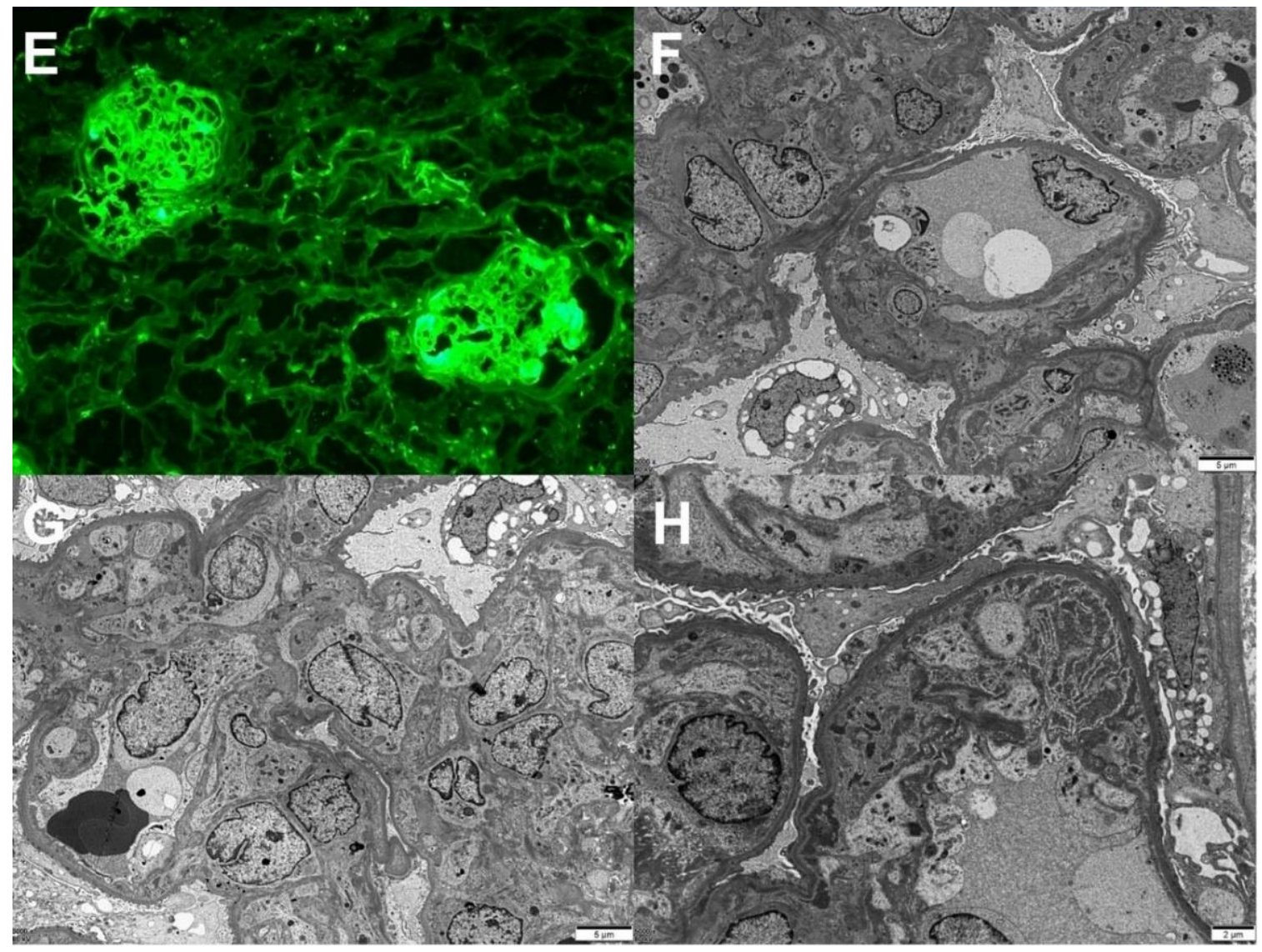

Figure 3. Pathologic findings of chronic thrombotic microangiopathy. Light microscopy: (A) In low magnification, no tubular atrophy or interstitial fibrosis was present (hematoxylin and eosin, $\times 40$ ). (B) The picture shows the duplication of the capillary basement membrane (arrow) (periodic acid methenamine silver, $\times 400$ ). (C) The glomerular lumina were occluded due to the thickening of the glomerular capillary wall with a few fibrin thrombi (arrow) (Masson's trichrome, $\times 400$ ). (D) Immunohistochemical stain for CD61 (platelet glycoprotein GPIIIa) shows positivity against platelet thrombi (CD61, $\times 400)$. Immunofluorescence: (E) Strong positive staining for fibrinogen in the glomerulus was observed $(\times 100)$. Electron microscopy: $(\mathbf{F})$ Glomerular basement membrane duplication with cellular interpositions was observed $(\times 3000,80 \mathrm{kv})$. (G) Glomerular endothelial swelling and hypertrophy with occlusion of the lumens (glomerular endotheliosis) and diffuse foot process effacements along the capillary surfaces were observed $(\times 3000,80 \mathrm{kv})$. $(\mathbf{H})$ Deposition of fibrinogen in the glomerular intracapillary area with entrapped cellular debris was noticed $(\times 5000,80 \mathrm{kv})$.

\subsection{Acute Tubulointerstitial Nephritis Presenting with Acute Kidney Injury}

A 44-year-old man with a chronic hepatitis B infection and type 2 diabetes mellitus visited the nephrology clinic because of decreased renal function. His baseline serum creatinine level was $0.91 \mathrm{mg} / \mathrm{dL}$; however, it increased to $4.94 \mathrm{mg} / \mathrm{dL}$ upon admission. He received the first dose of the mRNA-1273 vaccine 3 weeks prior to his visit, and gastrointestinal discomfort and anorexia occurred 1 day after vaccination. His general condition did not improve, so he visited a local clinic and exhibited a serum creatinine level of $4.13 \mathrm{mg} / \mathrm{dL} 1$ week after vaccination. He did not take any nephrotoxic agents and drank enough water, but his azotemia worsened. The laboratory examinations revealed a spot urine protein-to-creatinine ratio of $1.0 \mathrm{~g} / \mathrm{g}$ and no microscopic hematuria, and the serologic markers for glomerulonephritis were all negative except for hepatitis B. A kidney biopsy was performed 28 days after the vaccination, and the results are shown in Figure 4. Light microscopy revealed massive inflammatory cell infiltration in the interstitium and tubular epithelium. The inflammatory cells consisted of mononuclear cells, neutrophils, eosinophils, and plasma cells. Immunofluorescence and electron microscopy revealed 
normal pathology. A high-dose steroid treatment (prednisolon $60 \mathrm{mg}$ /day) was applied to treat acute tubulointerstitial nephritis. Six weeks later, his serum creatinine level was decreased to $1.89 \mathrm{mg} / \mathrm{dL}$, and his spot urine protein-to-creatinine ratio was $0.3 \mathrm{~g} / \mathrm{g}$.

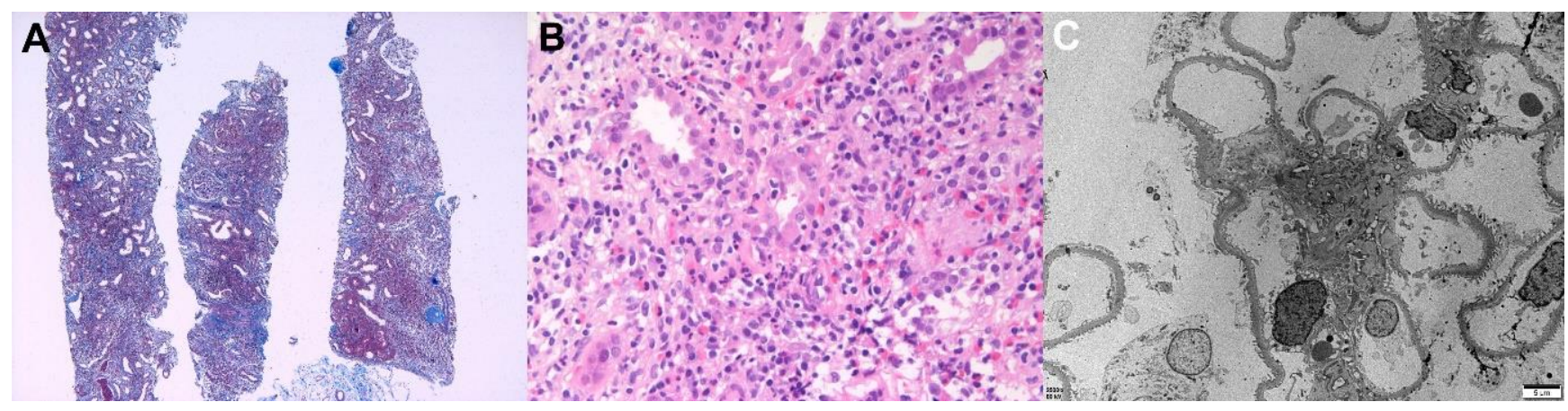

Figure 4. Pathologic findings of acute tubulointerstitial nephritis (patient 1). Light microscopy: (A) Massive interstitial inflammatory infiltrates with fibrosis (Masson's trichrome, $\times 40$ ) and (B) Mixed inflammatory cells infiltrated the tubular epithelium (tubulitis) and interstitium were observed. Large numbers of mononuclear cells, neutrophils, eosinophils, and plasma cells were present (hematoxylin and eosin, $\times 400$ ). Electron microscopy: (C) The glomerulus showed a relatively normal appearance. No electron-dense deposits with a normal thickness of basement membrane and intact foot processes were present $(\times 2500,80 \mathrm{kv})$.

A 77-year-old woman with a chronic hepatitis B infection, hepatocellular carcinoma, and type 2 diabetes mellitus visited the emergency room, presenting with anorexia and nausea following vaccination. She received the second dose of the BNT162b2 vaccine 7 days prior to her visit. The day after vaccination, she had experienced severe nausea and vomiting, so she received intravenous fluid therapy. Her symptoms did not improve, and 1 week after the vaccination, her serum creatinine level was increased from $0.98 \mathrm{mg} / \mathrm{dL}$ to $10.75 \mathrm{mg} / \mathrm{dL}$, and her bicarbonate level was decreased to $8.2 \mathrm{mmol} / \mathrm{L}$. Based on the serologic examination, her muscle enzyme levels were slightly increased (creatine phosphokinase $381 \mathrm{U} / \mathrm{L}$, lactate dehydrogenase $427 \mathrm{U} / \mathrm{L}$, and myoglobin $1180 \mathrm{ng} / \mathrm{mL}$ ), and the serologic markers were all negative except for hepatitis B surface antigen. Hemodialysis was initiated, and a kidney biopsy was performed 2 weeks after vaccination (Figure 5). Light microscopy revealed normal glomeruli, mild infiltration of lymphocytes in the interstitium, and myoglobin casts in the tubules. Electron dense casts in the tubules were also observed during the electron microscopy. No specific findings in immunofluorescence were recorded. Considering her condition, she underwent a low-dose steroid treatment (prednisolone $20 \mathrm{mg} /$ day), and her kidney function gradually recovered indicating a serum creatinine level of $2.12 \mathrm{mg} / \mathrm{dL} 4$ months after the vaccination. 

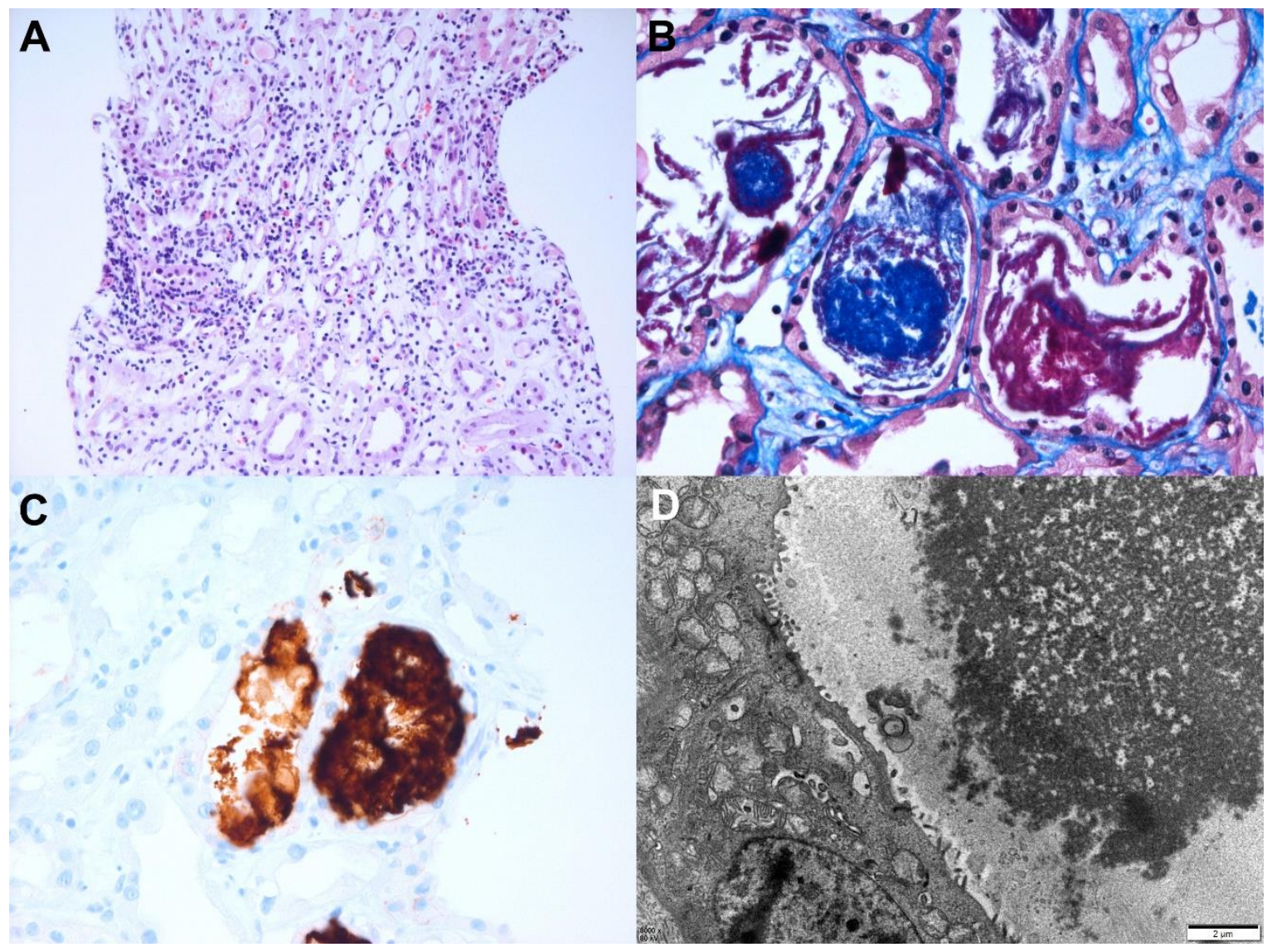

Figure 5. Pathologic findings of acute tubulointerstitial nephritis (patient 2). Light microscopy: (A) Mixed inflammatory cells infiltrated the tubular epithelium (tubulitis) and interstitium. Large numbers of mononuclear cells, neutrophils, eosinophils, and plasma cells were present (hematoxylin and eosin, $\times 400$ ). (B) Acute tubular injury with red granular casts and string-like appearing casts was observed(Masson's trichrome, $\times 400$ ). (C) The casts show strong myoglobin positivity in the immunohistochemical stain (myoglobin, $\times 400$ ). Electron microscopy: (D) The tubular casts have electron dense granules $(\times 8000,80 \mathrm{kv})$.

\section{Discussion}

In this report, we reviewed the clinical course, treatment, and histopathologic findings of various new-onset kidney diseases following COVID-19 vaccination. This is not a controlled study, so causality between vaccinations and these diseases cannot be concluded. However, COVID-19 vaccines are known to cause new-onset or relapsing glomerular diseases due to potent immune dysregulation, and various therapeutic responses have been reported [4,5]. Therefore, special attention is required for the onset of kidney disease symptoms in recently vaccinated patients, such as foamy urine, hematuria, and edema.

IgA nephropathy is the most common glomerulonephritis identified in kidney biopsy, and it is an immune complex disease caused by mesangial IgA1 deposition with or without concurrent $\operatorname{IgG}$ and $\mathrm{C} 3$ deposits [6,7]. Although the factors causing the occurrence of $\operatorname{Ig} \mathrm{A}$ nephropathy have not been clearly identified, IgA nephropathy is proposed as a multihit disease. If patients who have a genetic predisposition (genetic variation encoding galactosylation) are exposed to subsequent triggering events, such as infection, dietary and environmental stress lead to the production of anti-glycan IgA/IgG, and IgA nephropathy will occur [8]. Klomjit et al. reported in their study that COVID-19 vaccination was associated with glomerulonephritis, and 5 out of 13 patients were diagnosed with IgA nephropathy (4 new-onset and 1 relapse) [4]. Among them, the partial nephrectomy sample of one patient before vaccination indicated IgA deposition. Therefore, IgA nephropathy 
after COVID-19 vaccination may be the result of a flare. Moreover, the most common symptom of IgA nephropathy after a COVID-19 vaccination was gross hematuria, and most patients showed a self-limited clinical course without immunosuppression [4]. In addition, eight cases of relapse IgA nephropathy were recorded, and all of them spontaneously recovered within 2 weeks [4].

Minimal change disease (MCD) is a glomerular disease typically characterized by nephrotic-range proteinuria, diffuse foot process effacement in electron microscopy, and no specific abnormalities in light microscopy and immunofluorescence. It has also been confirmed that podocyte injury is caused by various circulating cytokines, such as interleukin (IL)-4, 5, 9, 10, and 13, which are released by activated T lymphocytes [3,9]. Recently, a Netherlands registry study showed podocyte-associated punctate polyclonal IgG deposits in MCD after COVID-19 vaccination, so B cell activation may also contribute to the onset of MCD to some degree [10]. Typical clinical and pathologic MCD features were confirmed in our case, which may be due to the potent immune response of the COVID-19 vaccine. Timmermans et al. also reported that biopsy-proven primary podocytopathies were significantly increased after COVID-19 vaccination compared with those before the COVID-19 pandemic, and incidences of MCD have since mainly increased [10]. These findings suggest a potential link between COVID-19 vaccinations and MCD. The patients responded well to steroid treatment, as did the general MCD cases. Some new-onset or relapse MCD cases after COVID-19 vaccination were reported, and most of them responded well to the high-dose steroid treatment and showed rapid remission [4,10-13]. However, one case showed no response to the high-dose steroid treatment, and complete remission was achieved after the administration of rituximab [4].

TMA refers to a spectrum of similar disease entities featured by microangiopathic hemolytic anemia, thrombocytopenia, and acute kidney injury, and can be caused by various etiologies [14]. TMA is characterized by the wall-thickening of microvessels (arterioles and capillaries), endothelial cells swelling and separating from the GBM, and blood clots containing platelets in the lumen of microvessels [15]. These narrow the vascular lumen, especially for microvessels, and lead to occlusion. Histopathological findings vary depending on the severity and duration of the TMA. Initially, the gap between the glomerular capillary endothelial cells and the GBM widens, leading to a thickening of the capillary wall. In the chronic phase, a new GBM is formed and makes two layers of GBM. Thrombi composed of a mass of destroyed red blood cells, fibrin, and platelets in the glomerular capillaries and mesangium can be observed $[15,16]$. However, the pathophysiologic mechanism of TMA after COVID-19 vaccination has not yet been clarified. Fabritiis et al. also reported a case of TMA after the BNT162b2 vaccination [17]. In this case, foamy urine was observed 5 weeks after the second dose of vaccination, and complete remission was achieved after steroid pulse therapy and high-dose steroid therapy. As in the case of TMA after influenza vaccination, complement activation by immune dysregulation is presumed to be involved in its occurrence [14], and as symptoms appeared early after vaccination, T lymphocytes may be an important mediator of vaccine-related TMA.

Acute tubulointerstitial nephritis (ATIN) can be caused by a hypersensitivity reaction from the use of various vaccines or drugs [18-20]. The development of ATIN is suggested to be caused by a T lymphocyte-mediated injury with an aberrant innate and consequent acquired immune response [21-23]. Ingredients found in COVID-19 vaccines, such as mRNA and polyethylene glycol, are known to be immunogenic agents and can induce a hypersensitivity-like reaction [22,24]. Some ATIN cases after COVID-19 vaccination have been observed and responded well to steroid treatment $[4,18]$. The occurrence of muscle syndromes, such as myalgia, myositis, and rhabdomyolysis, is a well-known side effect of vaccination [25]. Myalgia is a common side effect of COVID-19 vaccinations, and cases of rhabdomyolysis after vaccination have also been reported [25]. The myoglobin cast itself is known to rarely cause kidney injury, but it is known to cause renal toxicity, volume depletion, ischemia, hypotension, and acidic urine, so it is important for high-risk patients to have enough water intake [26]. 


\section{Conclusions}

This case series provides information on new-onset renal histopathology after COVID-19 vaccination. The need for COVID-19 vaccination, including booster shots, is being emphasized globally. Although we could not confirm causality between vaccinations and these phenomena, in this time of mass vaccination, clinicians need to consider the possibility that vaccines may have provoked kidney diseases in patients who have renal symptoms.

Author Contributions: Conceptualization: J.-H.L., M.-S.K. and S.-H.P. Investigation: J.-H.L., M.-S.K., Y.-J.K., M.-H.H., H.-Y.J., J.-Y.C., J.-H.C., C.-D.K., Y.-L.K. and S.-H.P. Writing and original draft preparation: J.-H.L. and M.-S.K. Writing and review and editing: J.-H.L. and S.-H.P. Visualization, M.-S.K. Supervision, S.-H.P. Funding acquisition, J.-H.C. All authors have read and agreed to the published version of the manuscript.

Funding: This research was supported by a grant from the Korea Health Technology R\&D Project through the Korea Health Industry Development Institute (KHIDI), funded by the Ministry of Health \& Welfare, Republic of Korea (grant number: HI15C0001), and by the Basic Science Research Program through the National Research Foundation of Korea (NRF) funded by the Ministry of Education (2021R1I1A3047973, 2021R1I1A3059702).

Institutional Review Board Statement: The study protocol was reviewed and approved by the Institutional Review Board of Kyungpook National University Hospital (2022-01-003).

Informed Consent Statement: The informed consent was waived since the study was conducted as a retrospective review of medical records.

Data Availability Statement: The data of this study is available from the corresponding author upon reasonable request.

Conflicts of Interest: The authors declare no conflict of interest.

\section{References}

1. Pilishvili, T.; Gierke, R.; Fleming-Dutra, K.E.; Farrar, J.L.; Mohr, N.M.; Talan, D.A.; Krishnadasan, A.; Harland, K.K.; Smithline, H.A.; Hou, P.C.; et al. Effectiveness of mRNA Covid-19 vaccine among U.S. Health care personnel. N. Engl. J. Med. 2021, 385, e90. [CrossRef]

2. Beatty, A.L.; Peyser, N.D.; Butcher, X.E.; Cocohoba, J.M.; Lin, F.; Olgin, J.E.; Pletcher, M.J.; Marcus, G.M. Analysis of COVID-19 vaccine type and adverse effects following vaccination. JAMA Netw. Open 2021, 4, e2140364. [CrossRef]

3. Lim, J.H.; Han, M.H.; Kim, Y.J.; Kim, M.S.; Jung, H.Y.; Choi, J.Y.; Cho, J.H.; Kim, C.D.; Kim, Y.L.; Park, S.H. New-onset nephrotic syndrome after Janssen COVID-19 vaccination: A case report and literature review. J. Korean Med. Sci. 2021, 36, e218. [CrossRef] [PubMed]

4. Klomjit, N.; Alexander, M.P.; Fervenza, F.C.; Zoghby, Z.; Garg, A.; Hogan, M.C.; Nasr, S.H.; Minshar, M.A.; Zand, L. COVID-19 vaccination and glomerulonephritis. Kidney Int. Rep. 2021, 6, 2969-2978. [CrossRef] [PubMed]

5. Bomback, A.S.; Kudose, S.; D'Agati, V.D. De novo and relapsing glomerular diseases after COVID-19 vaccination: What do we know so far? Am. J. Kidney Dis. 2021, 78, 477-480. [CrossRef] [PubMed]

6. Schena, F.P.; Nistor, I. Epidemiology of IgA nephropathy: A global perspective. Semin Nephrol. 2018, 38, 435-442. [CrossRef]

7. Yim, T.; Kim, S.U.; Park, S.; Lim, J.H.; Jung, H.Y.; Cho, J.H.; Kim, C.D.; Kim, Y.L.; Han, M.H.; Kim, Y.J.; et al. Patterns in renal diseases diagnosed by kidney biopsy: A single-center experience. Kidney Res. Clin. Pract. 2020, 39, 60-69. [CrossRef]

8. Lai, K.N. Pathogenesis of IgA nephropathy. Nat. Rev. Nephrol. 2012, 8, 275-283. [CrossRef] [PubMed]

9. Vivarelli, M.; Massella, L.; Ruggiero, B.; Emma, F. Minimal change disease. Clin. J. Am. Soc. Nephrol. 2017, 12, 332-345. [CrossRef]

10. Timmermans, S.A.M.E.G.; Busch, M.H.; Abdul-Hamid, M.A.; Frenken, L.A.M.; Aarnoudse, A.J.; van Paassen, P. Limburg Renal Registry Primary Podocytopathies following Covid-19 Vaccination. Kidney Int. Rep. 2021. [CrossRef] [PubMed]

11. D'Agati, V.D.; Kudose, S.; Bomback, A.S.; Adamidis, A.; Tartini, A. Minimal change disease and acute kidney injury following the Pfizer-BioNTech COVID-19 vaccine. Kidney Int. 2021, 100, 461-463. [CrossRef] [PubMed]

12. Kervella, D.; Jacquemont, L.; Chapelet-Debout, A.; Deltombe, C.; Ville, S. Minimal change disease relapse following SARS-CoV-2 mRNA vaccine. Kidney Int. 2021, 100, 457-458. [CrossRef]

13. Lebedev, L.; Sapojnikov, M.; Wechsler, A.; Varadi-Levi, R.; Zamir, D.; Tobar, A.; Levin-Iaina, N.; Fytlovich, S.; Yagil, Y. Minimal change disease following the Pfizer-BioNTech COVID-19 vaccine. Am. J. Kidney Dis. 2021, 78, 142-145. [CrossRef] [PubMed]

14. Bitzan, M.; Zieg, J. Influenza-associated thrombotic microangiopathies. Pediatr. Nephrol. 2018, 33, 2009-2025. [CrossRef] [PubMed]

15. Sol, M.Y. Pathology of thrombotic microangiopathy. J. Korean Soc. Pediatr. Nephrol. 2013, 17, 6-12. [CrossRef]

16. Ruggenenti, P.; Noris, M.; Remuzzi, G. Thrombotic microangiopathy, hemolytic uremic syndrome, and thrombotic thrombocytopenic purpura. Kidney Int. 2001, 60, 831-846. [CrossRef] [PubMed] 
17. De Fabritiis, M.; Angelini, M.L.; Fabbrizio, B.; Cenacchi, G.; Americo, C.; Cristino, S.; Lifrieri, M.F.; Cappuccilli, M.; Spazzoli, A.; Zambianchi, L.; et al. Renal thrombotic microangiopathy in concurrent COVID-19 vaccination and infection. Pathogens 2021, 10, 1045. [CrossRef]

18. Mira, F.S.; Costa Carvalho, J.; de Almeida, P.A.; Pimenta, A.C.; Alen Coutinho, I.; Figueiredo, C.; Rodrigues, L.; Sousa, V.; Ferreira, E.; Pinto, H.; et al. A case of acute interstitial nephritis after two doses of the BNT162b2 SARS-CoV-2 vaccine. Int. J. Nephrol. Renovasc. Dis. 2021, 14, 421-426. [CrossRef]

19. Koda, R.; Watanabe, H.; Tsuchida, M.; Iino, N.; Suzuki, K.; Hasegawa, G.; Imai, N.; Narita, I. Immune checkpoint inhibitor (nivolumab)-associated kidney injury and the importance of recognizing concomitant medications known to cause acute tubulointerstitial nephritis: A case report. BMC Nephrol. 2018, 19, 48. [CrossRef]

20. Kawamata, M.; Akimoto, T.; Sugase, T.; Otani-Takei, N.; Miki, T.; Masuda, T.; Kobayashi, T.; Takeda, S.; Muto, S.; Nagata, D. Tubulointerstitial nephritis and uveitis syndrome: Are drugs offenders or bystanders? Clin. Med. Insights Case Rep. 2016, 9, 21-24. [CrossRef]

21. Segal, Y.; Shoenfeld, Y. Vaccine-induced autoimmunity: The role of molecular mimicry and immune crossreaction. Cell Mol. Immunol. 2018, 15, 586-594. [CrossRef] [PubMed]

22. Caso, F.; Costa, L.; Ruscitti, P.; Navarini, L.; Del Puente, A.; Giacomelli, R.; Scarpa, R. Could Sars-coronavirus-2 trigger autoimmune and/or autoinflammatory mechanisms in genetically predisposed subjects? Autoimmun. Rev. 2020, $19,102524$. [CrossRef] [PubMed]

23. Sette, A.; Crotty, S. Adaptive immunity to SARS-CoV-2 and COVID-19. Cell 2021, 184, 861-880. [CrossRef] [PubMed]

24. Carvalho, J.C.; Cunha, F.; Coutinho, I.A.; Loureiro, C.; Faria, E.; Bom, A.T. Hypersensitivity reactions to vaccines: Current evidence and standards for SARS-CoV-2 vaccines. Acta Med. Port 2021, 34, 541-547. [CrossRef] [PubMed]

25. Nassar, M.; Chung, H.; Dhayaparan, Y.; Nyein, A.; Acevedo, B.J.; Chicos, C.; Zheng, D.; Barras, M.; Mohamed, M.; Alfishawy, M.; et al. COVID-19 vaccine induced rhabdomyolysis: Case report with literature review. Diabetes Metab. Syndr. 2021, 15, 102170. [CrossRef] [PubMed]

26. Gaut, J.P.; Liapis, H. Acute kidney injury pathology and pathophysiology: A retrospective review. Clin. Kidney J. 2021, 14, 526-536. [CrossRef] [PubMed] 